\title{
REFERENCES
}

Booth, V. H. (1956). Carotene, its Determination in Biological Materials. Cambridge: W. Heffer and Sons Ltd. (In the Press.)

Fisher, R. A. (1950). Statistical Methods for Research Workers, I Ith ed. Section 21.1. London: Oliver and Boyd.

Fraps, G. S. (1946). Arch. Biochem. ro, 485 .

Goodwin, T. W. (1955). In Modern Methods of Plant Analysis. Vol. 3, p. 272. [K. Paech and M. V. Tracey, editors.] Berlin: Springer.

Paul, M. F., Ells, V. R. \& Paul, H. E. (1951). Amer. Y. dig. Dis. 18, 278.

Ramasarma, G. B. \& Hakim, D. N. (1942). Ann. Biochem. 2, I 81 .

Sexton, E. L., Mehl, J. W. \& Deuel, H. J. Jr. (1946). F. Nutr. 3r, 299.

Sherman, W. C. (194I). F. Nutr. 22, I 53 .

Wagner, K. H., Günther, L. \& Schulze, L. (194I). Vitam. u. Horm. 1, 455.

With, T. K. (1940). Absorption, Metabolism and Storage of Vitamin $A$ and Carotene. Copenhagen: Munksgaard.

\section{The effect of calcium depletion on the chemical composition of bone minerals in laying hens}

\author{
By T. G. TAYLOR AND J. H. MOORE \\ Department of Agricultural Chemistry, University of Reading
}

(Received 12. March 1956)

In a previous experiment (Taylor \& Moore, 1954) progressive mineral depletion was induced in pullets by allowing them to lay two, four or six eggs while on a calciumdeficient diet, and the degree of depletion suffered by individual bones was assessed by comparing their total ash content with that of corresponding bones from control birds which did not receive the deficient diet. Great variations were found in the extent to which the different bones had been affected. Whereas, for example, the skull, metatarsi and toes lost only small quantities of minerals, the ribs, sternum, ilia, ischia and pubis suffered severely.

In this paper the detailed chemical composition of selected bone materials from these pullets is reported, and the results are discussed in relation to current theories on the chemical nature of bone salts and on the mechanism by which minerals are lost from the skeleton.

The bones which, in the depleted birds, experienced severe loss of minerals are termed 'labile' and those which suffered only slightly 'non-labile', and one example of each type of bone and two samples of medullary bone were analysed from each pullet.

\section{EXPERIMENTAL}

Birds and their treatment. Eight Light Sussex pullets, judged as being due to lay in about a month, were placed in separate metabolism cages and fed a laying ration containing $2 \cdot 04 \% \mathrm{Ca}$. After they had laid three eggs on this ration, six of the birds were given a low-Ca diet $(0.054 \% \mathrm{Ca})$ by withholding the supplement of calcium carbonate from the standard ration. The other two birds, which were to act as controls, 
were killed immediately after laying their third egg on the normal-Ca ration. Of the remaining birds, two were allowed to lay two eggs, two, four eggs and two, six eggs on the low-Ca ration, and all were killed immediately after the required number of eggs had been laid.

The treatments received by the individual birds and the number of days they were fed on the low-Ca diet are given in Table $\mathrm{I}$.

Bone material. The 'labile' bones chosen for analysis were the ilia, ischia, clavicle, coracoids, sternum and ribs, and the 'non-labile' ones were the metatarsi and toes. The estimated percentage losses of minerals which these bones suffered are given in Table r.

Table I. Estimated percentage loss of minerals suffered by the various cortical bones, and the treatments received by the experimental hens

\begin{tabular}{|c|c|c|c|c|c|}
\hline $\begin{array}{l}\text { Sample } \\
\text { no. }\end{array}$ & $\begin{array}{c}\text { Bird } \\
\text { no. }\end{array}$ & $\begin{array}{c}\text { Days on } \\
\text { low-Ca } \\
\text { diet }\end{array}$ & $\begin{array}{c}\text { No. of eggs } \\
\text { on low-Ca } \\
\text { diet }\end{array}$ & Bone & $\begin{array}{l}\text { Mean percentage } \\
\text { loss (weighted) }\end{array}$ \\
\hline \multicolumn{6}{|c|}{ 'Non-labile' bones } \\
\hline I & 3 & o & o & Metatarsi & $\circ$ \\
\hline 2 & 8 & $\circ$ & 0 & Metatarsi and toes & $\circ$ \\
\hline 3 & 5 & 3 & 2 & Metatarsi & 0 \\
\hline 4 & 7 & 2 & 2 & Metatarsi & 0 \\
\hline 5 & 4 & 4 & 4 & Metatarsi & 9 \\
\hline 6 & 6 & 4 & 4 & Metatarsi and toes & 16 \\
\hline 7 & $\mathbf{I}$ & I0 & 6 & Metatarsi & 19 \\
\hline 8 & 2 & 12 & 6 & Metatarsi & 22 \\
\hline \multicolumn{6}{|c|}{ 'Labile' bones } \\
\hline 9 & 3 & $\circ$ & 0 & Ilia and ischia & $\circ$ \\
\hline Io & 8 & $\circ$ & $\circ$ & All six* & $\circ$ \\
\hline I I & 5 & 3 & 2 & Ilia and ischia & 40 \\
\hline 12 & 7 & 2 & 2 & All six* & 28 \\
\hline 13 & 4 & 4 & 4 & Ilia and ischia & 40 \\
\hline 14 & 6 & 4 & 4 & Ilia and ischia & 47 \\
\hline I 5 & $\mathbf{I}$ & Io & 6 & Ilia and ischia & 53 \\
\hline 16 & 2 & 12 & 6 & All six* & 59 \\
\hline
\end{tabular}

The initial preparation of the bones and the separation of the medullary from the cortical bone were described in the original paper (Taylor \& Moore, I954). After fat extraction, all bone materials were ground to pass a 300 -mesh (B.S.) sieve and further purified by centrifuging with carbon tetrachloride. Non-osseous and poorly calcified materials float in this liquid, whereas well-calcified material sinks.

Analytical methods. Carbon dioxide was determined by the method of Tinsley, Taylor \& Moore (195I), the gas being liberated from the bone powder with $0.2 \mathrm{~N}$ hydrochloric acid, and $\mathrm{Ca}$, phosphorus and magnesium were determined on portions of the filtered acid extracts after they had been subjected to a nitric acid-perchloric acid digestion to remove organic matter (Gerritz, I935). Ca was precipitated as oxalate in a $15 \mathrm{ml}$. centrifuge tube and, after one washing with ammonia solution $(2 \%(\mathrm{v} / \mathrm{v})$ ammonia sp.gr. 0.88 ) containing the surface-active product Dispersol-VL at a dilution of $0.02 \%(\mathrm{v} / \mathrm{v})$ to prevent creeping, the precipitate was dissolved in $2 \mathrm{ml}$. $0 . \mathrm{I} \mathrm{N}$ ceric- 
sulphate solution by heating on a water-bath. After cooling, the excess ceric sulphate was titrated with $0.03 \mathrm{~N}$ ferrous ammonium sulphate, with 0 -phenanthroline ferrous complex as indicator. Phosphate was determined colorimetrically by the method of Koenig \& Johnson (1942) as modified by Kitson \& Mellon (1944) in a Spekker absorptiometer. $\mathrm{Mg}$ was determined by a modification (Taylor, 1955) of the method of Hunter (1950). Sodium and potassium were determined in N nitric-acid extracts of the bone powder with an EEL flame photometer. In the $\mathrm{Na}$ determinations the $\mathrm{Ca}$ present in the unknown solutions was compensated for by incorporating the same amount of $\mathrm{Ca}$ in the $\mathrm{Na}$ standards, and the $\mathrm{K}$ standards were compensated for the $\mathrm{P}$ present in the bone extracts in a similar manner. With the cortical bone samples $\mathrm{Na}$ and $\mathrm{K}$ determinations were also made on $\mathrm{N}$ nitric-acid extracts of the ash.

Determinations of total ash were made by heating in an electric furnace at $600^{\circ}$ for $24 \mathrm{~h}$. When the crucibles were cool, two drops of saturated ammonium-carbonate solution were added to each to regenerate any carbonate that might have been transformed into oxide. The ash was then heated in an oven at $120^{\circ}$ for $\mathrm{I} h$ before reweighing. Citric acid was determined by the method of Taylor (I953) on portions of the hydrochloric-acid extracts obtained in the carbon-dioxide determinations.

\section{RESULTS}

Loss of alkali metals on ashing. The effect of ashing at $600^{\circ}$ on the $\mathrm{Na}$ and $\mathrm{K}$ content of the 'labile' and 'non-labile' cortical bones is shown in Table 2. $\mathrm{K}$ losses during the ashing process varied from 67 to $83 \%$ of the total, and the two types of bone were equally affected. Losses of $\mathrm{Na}$ were more variable and there was a marked difference

Table 2. Sodium and potassium contents of air-dry cortical bones of hens determined by acid extraction and by ashing, and percentage losses resulting from ashing

\begin{tabular}{|c|c|c|c|c|c|c|}
\hline \multirow[b]{2}{*}{$\begin{array}{c}\text { Sample } \\
\text { no. }\end{array}$} & \multicolumn{3}{|c|}{ Sodium } & \multicolumn{3}{|c|}{ Potassium } \\
\hline & $\begin{array}{c}\text { By } \\
\text { extraction } \\
(\%)\end{array}$ & $\begin{array}{c}\text { By } \\
\text { ashing } \\
(\%)\end{array}$ & $\begin{array}{c}\text { Percentage } \\
\text { loss on } \\
\text { ashing }\end{array}$ & $\begin{array}{c}\text { By } \\
\text { extraction } \\
(\%)\end{array}$ & $\begin{array}{c}\text { By } \\
\text { ashing } \\
(\%)\end{array}$ & $\begin{array}{c}\text { Percentage } \\
\text { loss on } \\
\text { ashing }\end{array}$ \\
\hline \multicolumn{7}{|c|}{ 'Non-labile' bones } \\
\hline I & 0.50 & 0.32 & 36 & O.I 5 & 0.05 & 67 \\
\hline 2 & 0.54 & 0.37 & 33 & 0.15 & 0.05 & 67 \\
\hline 3 & 0.50 & 0.33 & 34 & 0.14 & 0.03 & 79 \\
\hline 4 & 0.56 & 0.30 & 46 & 0.15 & 0.04 & 73 \\
\hline 5 & 0.49 & 0.33 & 33 & 0.15 & 0.04 & 73 \\
\hline 6 & 0.46 & 0.32 & 30 & 0.18 & 0.04 & 78 \\
\hline 7 & 0.50 & 0.42 & 16 & 0.21 & 0.07 & 67 \\
\hline 8 & 0.50 & 0.42 & 25 & 0.18 & 0.06 & 67 \\
\hline \multicolumn{7}{|c|}{ 'Labile' bones } \\
\hline 9 & 0.47 & 0.47 & 0 & 0.36 & 0.06 & 83 \\
\hline 10 & 0.51 & $0: 45$ & 12 & 0.32 & $0 \cdot 06$ & 81 \\
\hline I I & $0 \cdot 47$ & 0.45 & 4 & $0.3 \mathrm{I}$ & 0.07 & 80 \\
\hline 12 & $0.5 \mathrm{I}$ & 0.50 & 2 & 0.32 & 0.10 & 70 \\
\hline I 3 & 0.64 & 0.58 & 9 & 0.56 & 0.13 & 77 \\
\hline 14 & 0.55 & 0.55 & 0 & 0.54 & 0.13 & 76 \\
\hline I 5 & 0.63 & 0.63 & 0 & 0.65 & 0.21 & 68 \\
\hline 16 & 0.67 & 0.60 & 5 & 0.52 & 0.13 & 75 \\
\hline
\end{tabular}


between the two types of bone. With the slightly depleted samples losses varied from 16 to $46 \%$, but with the seriously depleted bone materials the range was $0-12 \%$ of the total.

Composition of the cortical bone. After the bone samples had been analysed the percentage total oxides was calculated for each, and there was good agreement between these figures and the experimentally determined ash percentages, after the latter had been corrected for the losses of $\mathrm{Na}$ and $\mathrm{K}$ and for the loss involved in the conversion of citrate into carbonate (Table 3 ). (Total oxides $=\mathrm{CaO}+\mathrm{MgO}+\mathrm{Na}_{2} \mathrm{O}+\mathrm{K}_{2} \mathrm{O}+\mathrm{P}_{2} \mathrm{O}_{5}+$ $\mathrm{CO}_{2}+$ citric acid expressed as 'anhydride', i.e. just as $\mathrm{Ca}_{3}\left(\mathrm{PO}_{4}\right)_{2}={ }_{3} \mathrm{CaO}+\mathrm{P}_{2} \mathrm{O}_{5}$, $\mathrm{Ca}_{3}\left(\mathrm{C}_{6} \mathrm{H}_{5} \mathrm{O}_{7}\right)_{2}$ (calcium citrate) $={ }_{3} \mathrm{CaO}+\mathrm{C}_{12} \mathrm{H}_{10} \mathrm{O}_{11}$ ('citrate anhydride').) It is clear, therefore, that there can have been no large undetermined fraction. In view of the corrections which must be applied to experimentally determined ash percentages, the calculated ash percentages (total oxides) were considered to be more reliable and they were therefore used in calculating the composition of the mineral matter of the bone samples.

There were some marked differences between the two types of bone as shown by the values for the control birds, in which changes introduced by different degrees of mineral depletion did not arise. The most striking difference was in the $\mathrm{K}$, the level of which was more than twice as great in the 'labile' bones as in the metatarsi and toes. The citrate was higher in the former, but the $\mathrm{Ca}$ and carbon dioxide were lower (Table 3 ). It is recognized that the $\mathrm{CO}_{2}$ of bone is chemically combined, but it has not been established whether it is present as carbonate or bicarbonate (Neuman \& Neuman, 1953).

The treatment effects can best be studied by comparing the composition of the bones from particular birds with the composition of the corresponding bones from birds at the previous stage of depletion. The 'non-labile' bones of the control birds and of those which laid two and four eggs on the Ca-deficient diet did not differ greatly from one another. The metatarsi from the birds which had laid six eggs on the deficient ration were, however, somewhat lower in $\mathrm{CO}_{2}$ and higher in $\mathrm{P}, \mathrm{Mg}$ and $\mathrm{K}$ than the controls.

During the calcification of the first two eggs on the low-Ca diet the mean loss of ash experienced by the 'labile' bones was no less than $34 \%$ of the amount initially present (Table I). In spite of this very severe depletion, which occurred in 3 days with bird no. 5 and in 2 days with bird no. 7 , the chemical changes that were induced were relatively slight, apart from a marked reduction in the $\mathrm{CO}_{2}$. With bird no. 7 , however, the citrate was low compared with that in the controls, and the $\mathrm{Mg}$ and $\mathrm{P}$ were slightly higher.

While the third and fourth eggs were being calcified on the deficient diet, the ilia and ischia suffered little or no further loss of minerals. During this stage of depletion the calcium for the egg-shells was provided by other bones (Taylor \& Moore, 1954). Nevertheless, some remarkable changes occurred in the ilia and ischia during this time. Very large increases in their $\mathrm{Na}$ and $\mathrm{K}$ contents took place. The bones of the four-egg pullets contained almost twice as much $\mathrm{K}$ as the corresponding bones of the two-egg birds. The $\mathrm{Mg}$ level rose slightly, and there was a marked fall in the Ca 


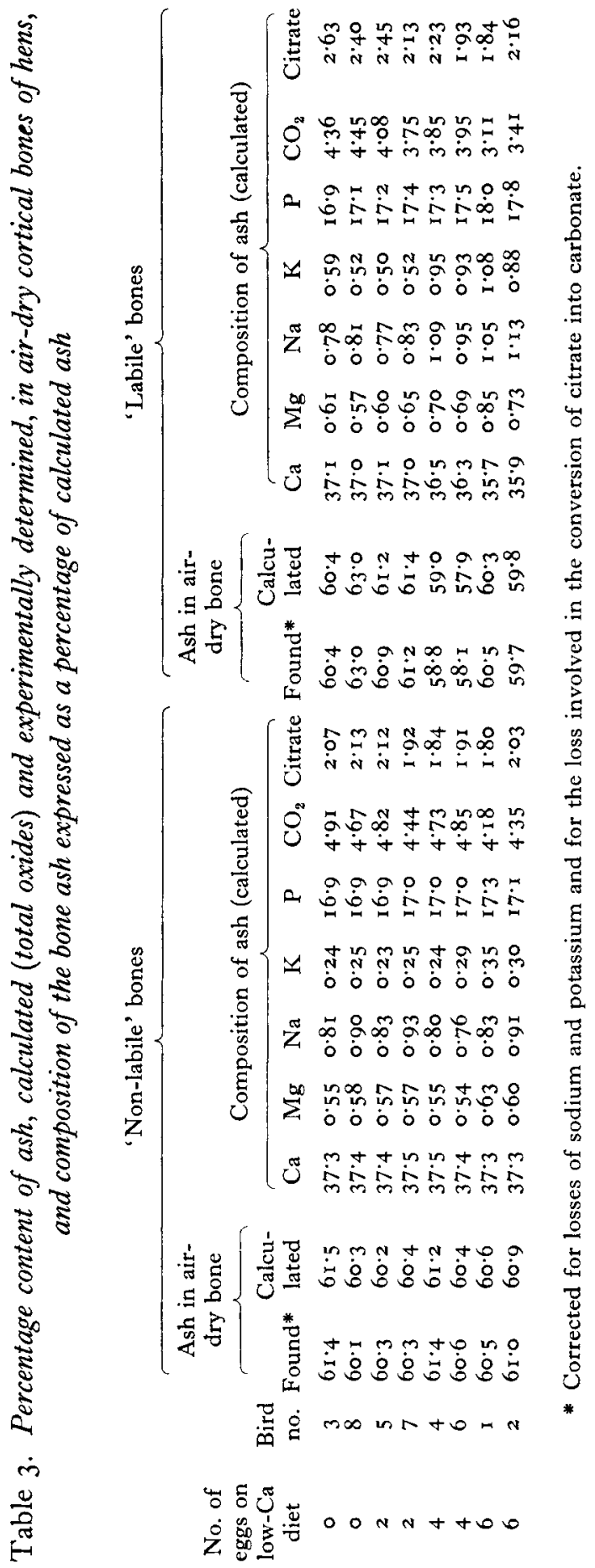


content. Little change occurred in the $\mathrm{CO}_{2}$ content of the bones from either of the four-egg birds, but the citrate content fell in bird no. 6 .

Mineral depletion of these bones was resumed during the calcification of the fifth and sixth eggs on the low-Ca diet. During this period the $\mathrm{Ca}$ and $\mathrm{CO}_{2}$ continued to fall and the $\mathrm{Mg}$ to rise, and there was a marked increase in the $\mathrm{P}$ content which up to this stage had been rising only slightly. In bird no. 2 the $\mathrm{Na}$, and in bird no. I the $\mathrm{K}$, reached levels still higher than those observed in the four-egg birds.

The composition of the mineral loss from the 'labile' bones at each stage may be estimated from the percentage loss of minerals of each bone given in Table r. The losses of the individual mineral constituents were calculated for each bone by subtracting the weight of each constituent present after depletion from the weight calculated to have been present before. The individual weights for the bones of the two-egg birds were subtracted from the mean weights of the control bones, and the mean weight of each constituent in the bones from the two-egg and four-egg birds was used to calculate the losses suffered, respectively, by the corresponding bones from the individual pullets which had laid four or six eggs on the deficient diet. The mineral losses (or gains) of the 'labile' bones based on mean ash weights of $5.00,3.30$ and $2.83 \mathrm{~g}$ for the control, two-egg and four-egg birds, respectively, are given in Table 4 .

Table 4. Weights ( $\mathrm{mg}$ ) of minerals estimated to have been lost or gained by the ilia and ischia at each stage of the skeletal depletion of hens

$\begin{array}{ccccccccc}\begin{array}{c}\text { Stage of } \\ \text { depletion }\end{array} & \begin{array}{c}\text { Bird } \\ \text { no. }\end{array} & \mathrm{Ca} & \mathrm{Mg} & \mathrm{Na} & \mathrm{K} & \mathrm{P} & \mathrm{CO}_{2} & \text { Citrate } \\ 0-2 \text { eggs } & 5 & -743 & -12 & -17 & -12 & -337 & -99 & -53 \\ & 7 & -523 & -6 & -10 & -9 & -226 & -86 & -50 \\ 2-4 \text { eggs } & 4 & -18 & +3 & +10 & +13 & +6 & -7 & -7 \\ & 6 & -142 & +* & +2 & +10 & -47 & -17 & -23 \\ 4-6 \text { eggs } & \mathrm{I} & -186 & -\dagger & -4 & -\mathrm{I} & -67 & -37 & -16 \\ & 2 & -293 & -5 & -6 & -9 & -128 & -40 & -15 \\ & & & \end{array}$

The most interesting information revealed by these calculations is that the large increases in the percentage of $\mathrm{Mg}, \mathrm{Na}$ and $\mathrm{K}$ shown by the bones from the four-egg birds compared with those of the two-egg pullets were due to increases in the actual amounts of these elements present, and not simply to reduction in the amounts of the other constituents. These increases were shown by the 'labile' bones of both birds on this treatment, in spite of the fact that there were considerable differences between birds in the magnitude of the losses of total mineral matter suffered by these particular bones at this stage of depletion.

Composition of the medullary bone. Bird no. I, which laid six eggs on the Ca-deficient ration, had medullary bone exceptionally low in ash, but with all the other birds the ash content of the carbon tetrachloride-purified bone was within the normal range. It is useful to compare the analytical values for the medullary bone with the corresponding values for the 'labile' cortical bones (Table 5). The general trends associated with increasing skeletal depletion were the same as in the cortical bones, although certain differences were apparent. In general the medullary-bone ash was lower in $\mathrm{Ca}$ and 
citrate and higher in $\mathrm{Mg}, \mathrm{Na}$ and $\mathrm{K}$ than the ash of the 'labile' cortical bones from the same pullet.

The $\mathrm{Mg}$, $\mathrm{Na}$ and $\mathrm{K}$ percentages in the medullary-bone ash of the control, two-egg and four-egg birds were all of the same order as in the 'labile' cortical bones from the six-egg pullets. (The $\mathrm{K}$ content of the medullary-bone ash from birds nos. 5 and 8 was exceptionally low, though still higher than that of the corresponding 'labile' cortical bones.) The medullary-bone ash from the six-egg pullets contained substantially more $\mathrm{Mg}, \mathrm{Na}, \mathrm{K}$ and, in general, $\mathrm{P}$, and less $\mathrm{Ca}, \mathrm{CO}_{2}$ and citrate than in the other six experimental birds.

Table 5. Calculated percentage content of ash (total oxides) of dry carbon tetrachloridepurified medullary-bone samples of hens and composition of the bone ash expressed as a percentage of calculated ash

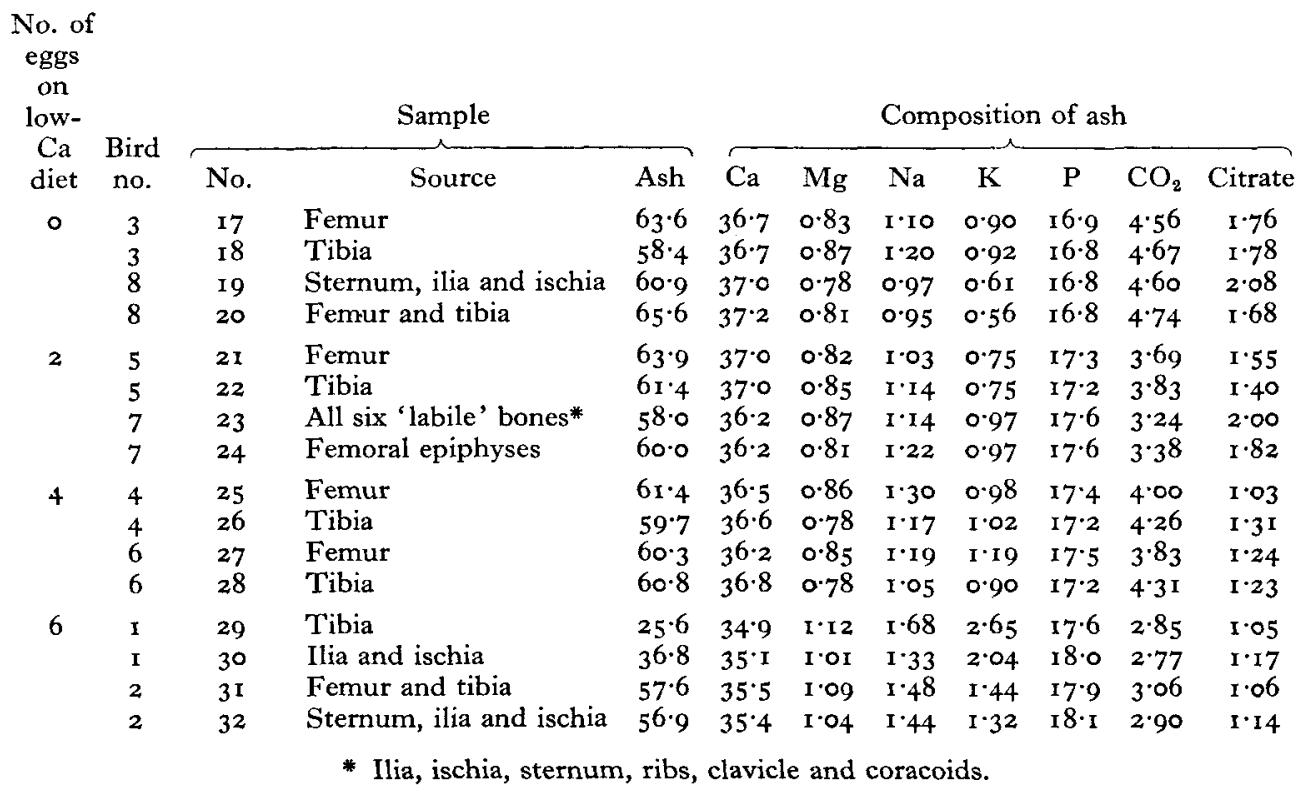

In the control birds the $\mathrm{CO}_{2}$ content of the medullary-bone ash was higher than that of the 'labile' cortical bone. With the two- and six-egg birds the carbon-dioxide content of the medullary ash was less than that of the 'labile'-bone ash, but it is surprising to note that in the four-egg birds the reverse was true.

Total Ca: total $P$ and residual Ca: residual $P$ weight ratios of cortical and medullary bone (Table 6). Residual Ca:residual $\mathrm{P}$ ratios are commonly calculated in order to obtain information on the nature of the mineral forming the apatite lattice of bone and tooth minerals. In making these calculations it was assumed that the $\mathrm{CO}_{2}$ and citrate were present in combination with $\mathrm{Ca}$, and that the $\mathrm{Mg}, \mathrm{Na}$ and $\mathrm{K}$ were present as phosphate. Residual $\mathrm{Ca}$ was obtained by subtracting the $\mathrm{Ca}$ present as citrate and carbonate (or bicarbonate) from the total $\mathrm{Ca}$, and residual $\mathrm{P}$ by subtracting the $\mathrm{P}$ combined with $\mathrm{Mg}, \mathrm{Na}$ and $\mathrm{K}$ from the total $\mathrm{P}$. 
The range of variation of the residual ratios was much less than that for the total Ca:total $\mathrm{P}$ ratios. With the cortical-bone samples the total $\mathrm{Ca}$ :total $\mathrm{P}$ weight ratios varied from $\mathrm{I}_{9} 98$ to $2 \cdot 22$ (mean $2 \cdot \mathrm{I}_{5}$ ) and the residual weight ratios with $\mathrm{CO}_{2}$ calculated as bicarbonate ranged from $2 \cdot 04$ to $2 \cdot 17$ (mean $2 \cdot 13$ ). The corresponding ratios for the medullary-bone samples were $1 \cdot 95^{-2 \cdot 2 I}$ (mean $2 \cdot 09$ ) and $2 \cdot 08-2 \cdot 23$ (mean $2 \cdot 16)$.

Table 6. Weight ratios, total Ca:total $P$ and residual Ca:residual $P$ of cortical and medullary bone from the eight experimental hens

\begin{tabular}{|c|c|c|c|c|c|c|c|}
\hline \multicolumn{4}{|c|}{ Cortical bone } & \multicolumn{4}{|c|}{ Medullary bone } \\
\hline & \multicolumn{3}{|c|}{ Ratio } & \multirow[b]{3}{*}{$\begin{array}{c}\text { Sample } \\
\text { no. } \dagger\end{array}$} & \multicolumn{3}{|c|}{ Ratio } \\
\hline & \multicolumn{3}{|c|}{ Residual Ca:residual $\mathrm{P}$} & & \multirow[b]{2}{*}{$\begin{array}{c}\text { Total Ca: } \\
\text { total P }\end{array}$} & \multicolumn{2}{|c|}{ Residual Ca:residual $\mathrm{F}$} \\
\hline $\begin{array}{c}\text { Sample } \\
\text { no.* }\end{array}$ & $\begin{array}{c}\text { Total Ca: } \\
\text { total P }\end{array}$ & $\begin{array}{l}\mathrm{CO}_{2} \text { as } \\
\mathrm{CO}_{3}{ }^{2--}\end{array}$ & $\begin{array}{l}\mathrm{CO}_{2} \text { as } \\
\mathrm{HCO}_{3}^{-}\end{array}$ & & & $\begin{array}{c}\mathrm{CO}_{2} \text { as } \\
\mathrm{CO}_{3}^{2-}\end{array}$ & $\begin{array}{l}\mathrm{CO}_{2} \text { as } \\
\mathrm{HCO}_{3}{ }^{-}\end{array}$ \\
\hline \multicolumn{8}{|c|}{ 'Non-labile' bones } \\
\hline I & $2 \cdot 20$ & 2.00 & $\overbrace{2 \cdot 15}$ & 17 & 2.17 & 2.06 & 2.10 \\
\hline 2 & $2 \cdot 22$ & $2 \cdot 04$ & $2 \cdot 17$ & 18 & $2 \cdot 19$ & $2 \cdot 10$ & $2 \cdot 23$ \\
\hline 3 & $2 \cdot 21$ & $2 \cdot 02$ & $2 \cdot 15$ & 19 & $2 \cdot 19$ & $2 \cdot 06$ & $2 \cdot 19$ \\
\hline 4 & $2 \cdot 21$ & $2 \cdot 04$ & $2 \cdot 17$ & 20 & $2 \cdot 21$ & $2 \cdot 08$ & $2 \cdot 2 I$ \\
\hline 5 & $2 \cdot 20$ & $2 \cdot 02$ & $2 \cdot 15$ & $2 I$ & $2 \cdot 14$ & $2 \cdot 08$ & $2 \cdot 17$ \\
\hline 6 & $2 \cdot 19$ & $2 \cdot 00$ & $2 \cdot 13$ & 22 & $2 \cdot 15$ & $2 \cdot 10$ & $2 \cdot 21$ \\
\hline 7 & $2 \cdot 16$ & $2 \cdot 02$ & $2 \cdot 15$ & 23 & 2.06 & $2 \cdot 04$ & $2 \cdot I I$ \\
\hline 8 & $2 \cdot 18$ & $2 \cdot 02$ & $2 \cdot 15$ & 24 & $2 \cdot 06$ & 2.02 & $2 \cdot I I$ \\
\hline \multicolumn{8}{|c|}{ 'Labile' bones } \\
\hline & $2 \cdot 19$ & 2.02 & $2 \cdot 15$ & 25 & $2 \cdot 10$ & $2 \cdot 08$ & 2.17 \\
\hline 10 & $2 \cdot 17$ & $2 \cdot 00$ & $2 \cdot 13$ & 26 & $2 \cdot 12$ & 2.08 & $2 \cdot 17$ \\
\hline I I & $2 \cdot 16$ & 2.02 & $2 \cdot 13$ & 27 & 2.07 & 2.04 & $2 \cdot 13$ \\
\hline 12 & $2 \cdot 13$ & 2.02 & $2 \cdot I I$ & 28 & $2 \cdot 13$ & $2 \cdot 04$ & $2 \cdot 17$ \\
\hline 13 & $2 \cdot 10$ & 2.02 & $2 \cdot 13$ & 29 & $\mathrm{I} \cdot 98$ & $2 \cdot 10$ & $2 \cdot 19$ \\
\hline 14 & 2.07 & I. 98 & 2.08 & 30 & $I \cdot 95$ & 2.02 & 2.10 \\
\hline 15 & I. 98 & I·94 & 2.04 & $3 \mathrm{I}$ & $\mathrm{I} \cdot 98$ & 2.04 & $2 \cdot I I$ \\
\hline 16 & 2.02 & I.96 & 2.06 & 32 & $x \cdot 96$ & 2.00 & $2 \cdot 08$ \\
\hline
\end{tabular}

The mean residual Ca:residual $\mathrm{P}$ ratios for both cortical- and medullary-bone samples were close to $2 \cdot 15$, the ratio for hydroxylapatite, when $\mathrm{CO}_{2}$ was calculated as bicarbonate. When the $\mathrm{CO}_{2}$ was calculated as carbonate the mean residual $\mathrm{Ca}$ : residual $\mathrm{P}$ ratio for the cortical-bone samples was $2 \cdot 0 \mathrm{I}$ and for the medullary samples $2 \cdot 06$, both of which figures are widely removed from the ratio for tricalcium phosphate, I.94.

\section{DISCUSSION}

The losses of the alkali metals which occurred during the ashing process were so great that it is clear that this method cannot be used for the accurate determination of these elements in bone. Losses would no doubt have been less if the bone had been ashed at a lower temperature, but complete ashing is very slow at temperatures less than $600^{\circ}$. 
There appeared to be no correlation between the ash percentages of the cortical bones and the extent of their mineral depletion. For example, the ash percentage of the ilia and ischia of bird no. I, which laid six eggs on the deficient diet, was almost the same as in the corresponding bones from one of the control birds (bird no. 3 ). This lack of correlation lends support to the now widely accepted view that when minerals are lost from the skeleton the organic matrix is destroyed simultaneously (McLean \& Bloom, I94I).

The effects of extreme $\mathrm{Ca}$ depletion on the composition of the cortical bone may best be observed by comparing the composition of the 'labile' bones of the control and six-egg pullets, and it is seen that depletion results in reductions in the $\mathrm{Ca}, \mathrm{CO}_{2}$ and citrate and increases in the $\mathrm{Mg}, \mathrm{Na}, \mathrm{K}$, and $\mathrm{P}$ in the ash, changes similar to those observed by Common (1938) in similar circumstances. It is clear, however, that these changes were not simply due to bone resorption. The ilia and ischia of bird no. 5 (which laid two eggs on the deficient diet) were calculated to have lost $40 \%$ of the mineral matter in the 2 days during which the low-Ca ration was fed, and yet the mineral composition of these bones was, apart from a marked reduction in $\mathrm{CO}_{2}$, very similar to that in control bird no. 8, which had suffered no depletion at all. The ilia and ischia of bird no. 4 (which laid four eggs on the low-Ca ration) were also calculated to have lost $40 \%$ of the mineral matter present before depletion began, yet these bones underwent very substantial changes in composition, presumably during the 2 days when the third and fourth eggs were being calcified, but when little, if any, further resorption was taking place in these bones. In the 'labile' bones of bird no. 5 substantial resorption had little effect on their mineral composition, yet in bird no. 4 considerable changes occurred during a period when these particular bones were not being called upon to provide Ca for egg-shell calcification.

It is impossible to conceive that all the unresorbed crystals in the 'labile' cortical bones of the four-egg pullets underwent dissolution followed by reprecipitation in the 2 days during which the third and fourth eggs were being calcified, though it may have happened to a proportion of them, and it seems more reasonable to suppose that the observed changes were mainly the result of changes in the ions adsorbed on the crystal surfaces (Hendricks, 1952). The fact that bone minerals reflect the composition of the blood supplying them has been made abundantly clear by the work of Sobel, Rockenmacher \& Kramer (I945), and it is suggested that changes in the blood plasma were responsible for the changes which occurred in the bones of the experimental pullets. Common (I94I) has shown that there is a reduction in the alkali reserve of hens laying on a low-Ca ration, and this is the probable explanation of the decrease in the $\mathrm{CO}_{2}$ content of the 'labile' bones of the two-egg pullets compared with the controls. As a result of the reduction in the alkali reserve there would have been an increase in the $\mathrm{P}: \mathrm{CO}_{2}$ ratio of the plasma, and it is suggested that the unresorbed bone crystals came into equilibrium with the altered plasma by the uptake of phosphate and the release of carbonate or bicarbonate ions. Judging by the $\mathrm{CO}_{2}$ content of the 'labile' bones of the six-egg birds, the alkali reserve would appear to have been still further reduced with extreme depletion. No marked changes in the cation composition of the 'labile' cortical bones occurred during the calcification of the first two eggs on the 
deficient diet and it must be assumed that, if any changes occurred in the levels of the plasma cations during this period, they were too small or too transitory to affect the cortical bone.

The substantial decrease in the $\mathrm{Ca}$ and the increases in the $\mathrm{Mg}, \mathrm{Na}$ and $\mathrm{K}$ which occurred in the 'labile' bones of the pullets that had laid four eggs on the low-Ca ration may be explained on the assumption that the ionic $\mathrm{Ca}$ of the plasma was greatly reduced during the calcification of the third and fourth eggs, resulting in the replacement of the $\mathrm{Ca}$ ions adsorbed on the surfaces of the bone crystals by $\mathrm{Mg}, \mathrm{Na}$ and $\mathrm{K}$ ions. It will be remembered that these bones showed an actual increase in the total amounts of $\mathrm{Mg}, \mathrm{Na}$ and $\mathrm{K}$ present (Table 4 ). Deobald, Christiansen, Hart \& Halpin (1938) have demonstrated that the total $\mathrm{Ca}$ of the blood is reduced in hens laying on a low-Ca ration, but ionic $\mathrm{Ca}$ levels were not determined. It seems inevitable, however, that the ionic $\mathrm{Ca}$ would be reduced in these circumstances.

There was a gradual decrease in the citrate content of the 'labile' bones with increasing loss of minerals from the skeleton, which was probably due to a reduction of serum citrate associated with the reduction in ionic Ca. Alwall (1945), in experiments in which dogs were injected with a parathyroid preparation, has shown that there is a direct relationship between serum $\mathrm{Ca}$ and serum citrate, and Freeman $\&$ Chang (1950) found that the level of the serum citrate was reduced as hypocalcaemia developed in thyro-parathyroidectomized dogs. It seems fairly certain that bone citrate is adsorbed on to the surfaces of the bone crystals (Hendricks \& Hill, I950; Taylor, 1955), and it would be expected to come into rapid equilibrium with the plasma citrate.

During the calcification of the fifth and sixth eggs on the deficient diet the $\mathrm{Mg}, \mathrm{Na}$ and $\mathrm{K}$ remained high and even increased in some of the 'labile' bones, and a marked rise in $\mathrm{P}$ also occurred. The most probable explanation of these observations is that a substantial increase in the inorganic $P$ level of the blood occurred during this period, whereas, in earlier stages of depletion, it had increased only slightly. It is to be expected that the blood $\mathrm{P}$ would rise in hens laying on a low-Ca diet, as only the $\mathrm{Ca}$ of the bone mineral is required by the calcifying egg-shell and the $\mathrm{P}$, which is released concomitantly, is largely excreted (Common, 1932; Tyler \& Willcox, 1942). Feinberg, Hughes \& Scott (r937) have shown that there is an increase in the inorganic $P$ of the blood when active shell calcification is taking place, even on a ration adequately supplied with $\mathrm{Ca}$.

If the explanation advanced above for the changes observed in the 'labile' cortical bones is the correct one, then similar changes should have been induced in the 'non-labile' bones by the postulated blood changes. These bones certainly showed trends similar to those in the 'labile' ones, but the magnitude of the changes was much less. The $\mathrm{Na}$ and $\mathrm{K}$ percentages, however, appeared not to have been affected by the mineral depletion. When the two types of cortical bone were compared for each bird within a particular treatment (Table 3), it was generally observed that those with low $\mathrm{CO}_{2}$ and citrate values in their 'labile' bones also had low values for their metatarsi and toes. (The citrate content of the bones of the four-egg birds was exceptional.) There was a similar relationship between the bone $\mathrm{Na}$ and $\mathrm{K}$ of birds nos. I and 2 . The 'labile' bones of bird no. 2 were higher in $\mathrm{Na}$ than those of bird no. $\mathrm{I}$, and the 
same was true of the metatarsi. For K, bird no. I had the higher values in both 'labile' and 'non-labile' bones.

The most reasonable explanation for the differences observed between the two types of cortical bone is that the vascular supply to the 'non-labile' bones is considerably less than to the 'labile' ones. The relatively poor vascular supply to the former bones is, indeed, the probable explanation for the slight degree of resorption they experienced. It seems probable that the parathyroids were responsible for the bone resorption which occurred in the experimental birds, and that the bones with the best blood supply received the most parathyroid hormone and therefore suffered the greatest depletion. Landauer \& Zondek (I944) consider that the variations in the amount of medullary bone formed in the different bones of the avian skeleton under the influence of sex hormones is related to variations in their blood supply, and it is interesting to note that medullary bone is almost absent from the metatarsi and toes of laying hens, whereas the ilia and ischia are abundantly supplied with it (Taylor $\&$ Moore, 1953). A further (unpublished) observation we have made is that immature pullets possess haematopoietic tissue only in those bones that in the laying bird contain medullary bone, and this finding again underlines the close relationship between bone metabolism and vascular supply.

It is suggested, then, that the differences observed between the 'labile' and 'nonlabile' bones were not due primarily to differences in the extent of the mineral loss they suffered, but to differences in the rate at which equilibrium was established between the blood and the two types of bone. On this hypothesis, equilibrium had not been reached between the metatarsi and the blood at the time when the birds were killed, owing to the limited circulation which these bones possess.

As noted previously the percentages of $\mathrm{Mg}, \mathrm{Na}$ and $\mathrm{K}$ in the ash of the medullary bone from the control, two-egg and four-egg pullets were very similar to the percentages in the 'labile' cortical bones from the six-egg birds, which immediately suggests that the diffusible-Ca level of the plasma bathing the medullary bone was low. This suggestion is supported by the low citrate content of the medullary-bone ash compared with the ash of the 'labile' cortical bone. All the experimental birds were killed immediately after an egg had been laid, so that the medullary bone present would have been recently exposed to plasma from which $\mathrm{Ca}$ was being removed for egg-shell calcification. The drain on the blood $\mathrm{Ca}$ during shell formation is very great. A normal shell contains $\mathrm{I}^{-} 5^{-2} \cdot \mathrm{O} \mathrm{g} \mathrm{Ca}$ (as calcium carbonate) and it is formed in about $20 \mathrm{~h}$ (Conrad \& Scott, $\left.193^{8}\right)$, so that the mean rate at which $\mathrm{Ca}$ is removed from the blood is $75^{-}$ $100 \mathrm{mg} / \mathrm{h}$. (The total $\mathrm{Ca}$ circulating in the blood of a hen of average size is less than $50 \mathrm{mg}$ so the rate of turnover must be tremendous.) Some of the eggs laid on the low$\mathrm{Ca}$ diet had shells containing less than $\mathrm{I} \cdot 5 \mathrm{~g} \mathrm{Ca}$, but with the exception of the last two eggs laid by the six-egg birds no shell contained less than I·24 $\mathrm{g} \mathrm{Ca}$ (Taylor \& Moore, I954).

It would not be surprising if this rate of $\mathrm{Ca}$ loss resulted in a fall in the ionic $\mathrm{Ca}$ level of the blood, but unfortunately there is no direct experimental evidence in support of this suggestion, owing no doubt to the experimental difficulties attending the determination of ionic $\mathrm{Ca}$ in the blood of laying birds. Knowles, Hart \& Halpin (1935), 
Feinberg et al. (1937) and Deobald et al. (1938), however, have studied the changes which take place in the total blood $\mathrm{Ca}$ during the egg-laying cycle, and their values are consistent with the suggestion that there is a reduction in the ionic $\mathrm{Ca}$ of the blood during shell calcification. Deobald, Lease, Hart \& Halpin (1936), on the other hand, found that the blood $\mathrm{Ca}$ of individual birds varied only within narrow limits during a complete egg-laying cycle. Variations in the blood $\mathrm{Ca}$ of hens laying on a ration containing adequate amounts of $\mathrm{Ca}$ are bound to be influenced by the time of oviposition in relation to the time of feeding (Tyler, 1954), and this factor may be responsible in part for the lack of agreement between the various groups of workers as to the changes in the blood $\mathrm{Ca}$ which occur in the laying cycle.

The differences between the 'labile' and 'non-labile' cortical bones have been explained above on the basis of differences in the time taken for them to come into equilibrium with the blood, and the differences between the medullary bone and the 'labile' cortical bones may be explained in a similar manner. It is suggested that the fall in blood $\mathrm{Ca}$ which occurs during shell calcification is quite transient when the food contains adequate amounts of $\mathrm{Ca}$, so that the cortical bone does not respond appreciably to it, whereas the medullary bone with its extremely good vascular supply and intense metabolism comes into rapid equilibrium with the low-Ca blood.

Residual Ca:residual $\mathrm{P}$ ratios must be regarded as giving only approximate figures for the $\mathrm{Ca}: \mathrm{P}$ ratio of the mineral forming the apatite lattice, and the suggestion that this mineral appears more likely to be hydroxyl-apatite than tricalcium phosphate is not invalidated because some of the residual ratios varied somewhat from $2 \cdot 15$ (Table 6). In these calculations $\mathrm{Mg}$ was assumed to be present as $\mathrm{Mg}^{2+}$ ions, but if $\mathrm{MgOH}^{+}$ions existed in substantial amounts, which is not improbable (Hendricks \& Hill, I950; Taylor, I955), then the calculated ratios would have been too high. High ratios could also be caused by the adsorption of large amounts of $\mathrm{Ca}$, and low ratios by the presence of large amounts of adsorbed P. It seems probable that much of the adsorbed $\mathrm{P}$ would be in the form of secondary phosphate ions, since it is this phosphate ion which predominates in the blood, whereas in calculations of residual $\mathrm{Ca}$ : residual $\mathrm{P}$ all the $\mathrm{P}$ was assumed to be in the tertiary form. Adsorbed hydrogen and hydroxyl ions would also influence the calculated residual $\mathrm{Ca}$ :residual $\mathrm{P}$ ratios. Another factor which affects the residual $\mathrm{Ca}$ :residual $\mathrm{P}$ ratios of minerals possessing the hydroxyl-apatite structure is the size of the component crystals. The smaller the crystals the higher is the ratio, owing to the surface $\mathrm{Ca}$ ions forming a greater proportion of the total $\mathrm{Ca}$ (Arnold, 1950). It is clear from the above considerations that constant figures for the residual $\mathrm{Ca}$ : residual $\mathrm{P}$ ratios are not to be expected. In the past workers have calculated residual $\mathrm{Ca}$ : residual $\mathrm{P}$ ratios without taking into account the presence in bone of $\mathrm{Na}, \mathrm{K}$ and citrate (Morgulis, I93 I), and sometimes $\mathrm{Mg}$ also has been ignored (Burns \& Henderson, I935), but it is clear from the present work that the amounts of these minor constituents present in particular bone samples may be so great that they cannot be disregarded without introducing substantial errors into the calculations.

It has long been recognized that bone minerals exhibit considerable variations in chemical composition but, as far as the authors are aware, variations in one organism 
as great as those reported in the present paper have not previously been recognized. The most extreme variations were found in bird no. $\mathrm{r}$, and the composition of the ash of the three types of bone obtained from this bird is given in Table 7. Hendricks \&

Table 7. Composition of the metatarsi, ilia and ischia and of the medullary bone from the tibia of bird no. I expressed as percentages of calculated ash and as weight ratios, total Ca:total $P$ and residual Ca:residual $P$

\begin{tabular}{|c|c|c|c|c|c|c|c|c|c|}
\hline \multirow[b]{2}{*}{ Bone } & \multirow[b]{2}{*}{$\mathrm{Ca}$} & \multirow[b]{2}{*}{$\mathrm{Mg}$} & \multirow[b]{2}{*}{$\mathrm{Na}$} & \multirow[b]{2}{*}{$\mathbf{K}$} & \multirow[b]{2}{*}{$\mathbf{P}$} & \multirow[b]{2}{*}{$\mathrm{CO}_{2}$} & \multirow[b]{2}{*}{ Citrate } & \multicolumn{2}{|c|}{ Ratio, Ca:P } \\
\hline & & & & & & & & Total & Residual* \\
\hline Metatarsi & $37 \cdot 3$ & 0.63 & 0.83 & 0.35 & $17 \cdot 3$ & $4 \cdot 18$ & I. 80 & $2 \cdot 16$ & $2 \cdot 15$ \\
\hline Ilia and ischia & $35 \cdot 7$ & 0.85 & r.05 & $\mathrm{r} \cdot 08$ & $18 \cdot 0$ & $3 \times 11$ & I. 84 & I 98 & 2.04 \\
\hline Tibia (medullary) & 34.9 & $1 \cdot 12$ & I 68 & $2 \cdot 65$ & $17 \cdot 6$ & $2 \cdot 85$ & I.05 & $x \cdot 98$ & $2 \cdot 19$ \\
\hline
\end{tabular}

Hill (1950) and Taylor (1955) have suggested that variations in the composition of bone minerals are mainly due to variations in the amounts of the various ions adsorbed on the bone crystals and not to differences in the material forming the apatite lattice, and the variations observed in this experiment can most reasonably be explained on this basis.

\section{SUMMARY}

I. 'Labile' and 'non-labile' cortical and medullary bone obtained during the course of a previous experiment with laying hens (Taylor \& Moore, I954) were analysed. Progressive mineral depletion had been induced in these birds by allowing them to lay two, four or six eggs on a calcium-deficient ration.

2. Ashing at $600^{\circ}$ resulted in substantial losses of potassium from the cortical-bone material, and in smaller and more variable losses of sodium.

3. Mineral depletion was associated with increases in the magnesium, sodium, potassium and phosphate of the bone ash and with decreases in the calcium, carbon dioxide and citrate. These changes were more marked in the 'labile' than in the 'non-labile' cortical bones, but the greatest changes occurred in the medullary bone.

4. It is suggested that the above changes were due primarily to increased adsorption of $\mathrm{P}, \mathrm{Mg}, \mathrm{Na}$ and $\mathrm{K}$ and decreased adsorption of $\mathrm{Ca}, \mathrm{CO}_{2}$ and citrate on the bone crystals, and that they were reflexions of a reduction in the ionic $\mathrm{Ca}$, a reduction in citrate, an increase in inorganic $P$ and a lowering of the alkali reserve of the blood.

5. It is considered that the differences between the two types of cortical bone were primarily due to differences in vascular supply and not to the degree of depletion which they had suffered, and the same suggestion is offered in explanation of the differences observed between the 'labile' cortical bone and the medullary bone.

6. There was no correlation between the extent of mineral depletion and the ash content of individual bones, which lends support to the theory that loss of minerals from the skeleton is effected by bone resorption as opposed to bone demineralization.

7. Differences in the degree of mineral depletion suffered by individual bones are thought to be due to differences in the amount of parathyroid hormone to which they are exposed, which are again related to variations in their blood supply. 
8. Residual $\mathrm{Ca}$ : residual $\mathrm{P}$ ratios were calculated and the results were more consistent with the hydroxyl-apatite than with the tricalcium-phosphate theory of the nature of the crystal lattice of bone.

\section{REFERENCES}

Alwall, N. (1945). Acta med. scand. 122, 448. Quoted in Nutr. Abstr. Rev. (1945-6), 15, 727.

Arnold, P. W. (1950). Trans. Faraday Soc. 336, 1061 .

Burns, C. M. \& Henderson, N. (1935): Biochem. F. 29, 2385.

Common, R. H. (1932). F. agric. Sci. 22, 576.

Common, R. H. (1938). F. agric. Sci. 28, 347.

Common, R. H. (194I). F. agric. Sci. 3I, 28 I.

Conrad, R. M. \& Scott, H. M. (1938). Physiol. Rev. 18, 48I.

Deobald, H. J., Christiansen, J. B., Hart, E. B. \& Halpin, J. G. (1938). Poult. Sci. 17, I I4.

Deobald, H. J., Lease, E. J., Hart, E. B. \& Halpin, J. G. (1936). Poult. Sci. I $5,179$.

Feinberg, J. G., Hughes, J. S. \& Scott, H. M. (1937). Poult. Sci. 16, 132.

Freeman, S. \& Chang, T. S. (1950). Amer. F. Physiol. 160, 34 I.

Gerritz, H. W. (1935). Industr. Engng Chem. (Anal.), 7, I67.

Hendricks, S. B. (1952). Trans. Macy Conference on Metabolic Interrelations, 4, 185.

Hendricks, S. B. \& Hill, W. L. (1950). Proc. nat. Acad. Sci., Wash., 36, 731.

Hunter, J. G. (1950). Analyst, 75, 91.

Kitson, R. E. \& Mellon, M. G. (1944). Industr. Engng Chem. (Anal.), 16, 379.

Knowles, H. R., Hart, E. B. \& Halpin, J. G. (1935). Poult. Sci. 14, 83.

Koenig, R. A. \& Johnson, C. R. (1942). Industr. Engng Chem. (Anal.), 14, 155.

Landauer, W. \& Zondek, B. (1944). Amer. F. Path. $20,179$.

Mclean, F. C. \& Bloom, W. (I94I). Arch. Path. (Lab. Med.), 32, 315.

Morgulis, S. (193I). F. biol. Chem. 93, 455.

Neuman, W. F. \& Neuman, M. W. (1953). Chem. Rev. 53, r.

Sobel, A. E.; Rockenmacher, M. \& Kramer, B. (1945). F. biol. Chem. 159, 159.

Taylor, T. G. (1953). Biochem. $\mathcal{F . ~ 5 4 , ~} 48$.

Taylor, T. G. (I 955). The chemical nature of bone minerals. Ph.D. Thesis, University of Reading.

Taylor, T. G. \& Moore, J. H. (1953). Nature, Lond., 172, 504.

Taylor, T. G. \& Moore, J. H. (1954). Brit. F. Nutr. 8, I 12.

Tinsley, J., Taylor, 'T. G. \& Moore, J. H. (195I). Analyst, 76, 300.

Tyler, C. (1954). F. Sci. Fd Agric. 5, 335.

Tyler, C. \& Willcox, J. S. (1942). F. agric. Sci. 32, 43 . 